\title{
Article \\ Holographic Interferometry for Measuring the Effect of Thermal Modification on Wood Thermal Properties
}

\author{
Áron Hortobágyi, Elena Pivarčiová *(1) and Pavol Koleda \\ Department of Manufacturing and Automation Technology, Faculty of Technology, Technical University \\ in Zvolen, T. G. Masaryka 24, 96001 Zvolen, Slovakia; xhortobagyi@is.tuzvo.sk (Á.H.); \\ pavol.koleda@tuzvo.sk (P.K.) \\ * Correspondence: pivarciova@tuzvo.sk
}

Citation: Hortobágyi, Á.;

Pivarčiová, E.; Koleda, P. Holographic Interferometry for Measuring the Effect of Thermal Modification on Wood Thermal Properties. Appl. Sci. 2021, 11, 2516. https://doi.org/ 10.3390/app11062516

Academic Editor: Stefano Invernizzi

Received: 27 January 2021

Accepted: 8 March 2021

Published: 11 March 2021

Publisher's Note: MDPI stays neutral with regard to jurisdictional claims in published maps and institutional affiliations.

Copyright: (c) 2021 by the authors. Licensee MDPI, Basel, Switzerland. This article is an open access article distributed under the terms and conditions of the Creative Commons Attribution (CC BY) license (https:// creativecommons.org/licenses/by/ $4.0 /)$.
Abstract: The paper focuses on the use of holographic interferometry in the research of thermal modification and its effect on the heat transfer from the wood surface to the surrounding air. In the experiment, spruce wood samples modified at $160{ }^{\circ} \mathrm{C}, 180{ }^{\circ} \mathrm{C}, 200^{\circ} \mathrm{C}, 220^{\circ} \mathrm{C}$ and an unmodified control sample were used. A radiant heat source was placed under the sample. The top of the sample represented the boundary where the observed heat transfer occurred. The temperature fields above the sample were visualized by real-time holographic interferometry and the heat transfer coefficient $\alpha$ was calculated from the obtained interferograms. During the heating of the samples, a decrease of the heat transfer coefficient was observed. The heat transfer coefficient of the control unmodified sample decreased from a maximum of $\alpha=22.66 \mathrm{Wm}^{-2} \mathrm{~K}^{-1}$ to a minimum of $\alpha=8.6 \mathrm{Wm}^{-2} \mathrm{~K}^{-1}$. In comparison with these values, the heat transfer coefficients of the modified samples treated at 160 , 180,200 and $220{ }^{\circ} \mathrm{C}$, respectively, decreased to $99 \%, 93 \%, 68 \%$ and $51 \%$ of the maximal control value at the beginning of experiment and to $95 \%, 86 \%, 80 \%$ and $64 \%$ of the minimal control value by the end of the experiment. Moreover, an analysis of variance was used to determine the significance of the heat treatment effect on the heat transfer coefficient. A high significance $(p<5 \%)$ was observed between the control sample and the modified samples treated at $200{ }^{\circ} \mathrm{C}$ and $220^{\circ} \mathrm{C}$. Experiments with the use of holographic interferometry produced results consistent with previous studies conducted by different methods.

Keywords: thermal modification; holographic interferometry; heat transfer; spruce wood; heat transfer coefficient

\section{Introduction}

When choosing a building material, several criteria are considered such as its strength, insulation properties, availability, workability, price and appearance. Wood and its composites are good materials for building construction and the creation of structural elements. Another use of wood is in the form of roof cladding where, due to good properties, it has never ceased to be used to a certain extent [1]. It has been used by humans for these and many other purposes since time immemorial. To further improve its properties, thermal modification is used. During modification, the wood is exposed to a high temperature in a controlled environment. Due to heating, permanent chemical changes occur, which lead to a decreased moisture content that results in the reduction of swelling and shrinkage. Biological durability is improved, color darkens, wood becomes lighter, equilibrium moisture content decreases, the $\mathrm{pH}$ decreases and thermal insulation properties are improved. On the other hand, the rigidity and strength of wood are affected by this process [2].

With such a treatment, the wood acquires a higher resistance to moisture and biodeterioration, which slows down its degradation and prolongs its life.

The dimensional stability of wood during thermal modification was investigated by Stam and Hansen [3]. Seborg, Millet and Stamm [4] tested the properties of modified 
staypack wood, shaped under increased temperature and humidity conditions. Kollmann and Scheider [5] focused on the absorption properties of thermally modified wood. Burmester [6] investigated thermal modification as a method to improve the dimensional stability of wood. Giebeler also addressed this issue [7].

Reinprecht and Vidholdová [8] investigated the mechanical properties and mold resistance of thermally modified wood. Boonstra [9] described the changes in wood that occurs during a two-phase thermal modification of wood. Niemz, Hoffmann and Rétfalvi [10] studied structural changes in thermally modified wood. Kol and Keshin [11] compared the thermal conductivity of wooden samples with different degrees of thermal modification. Kol and Sefil [12] researched thermal conductivity of fir and beech wood modified at various temperatures. Korkut [13] studied the effects of heat treatment on the surface characteristics of wild cherry wood. Olarescu [14] researched the thermal conductivity of solid wood panels made from heat treated spruce and lime wood strips. Pásztory [15] led research on the effect of heat treatment duration on the thermal conductivity of spruce and poplar wood. Czajkowski [16] studied the effect of heat treatment on the thermal properties of European beech wood.

Barcík [17] dealt with the influence of the tool and the parameters of abrasive machining on the chip size of thermally modified wood. Kol [18] observed a change in the properties of wood that had been modified at different temperatures. Kubs [19] investigated the effect of the thermal modification of pine wood on the energy consumption of a milling machine. Koleda [20] solved a similar topic with samples from spruce wood and Korčok [21] compared the quality of milled surfaces on samples modified at different temperatures.

Cui and Matsumura [22] observed changes in the color of the surface of thermally modified wood during the weathering process. Kačíková [23] dealt with the change of lignin in wood due to thermal modification. Kminiak [24] investigated the particle size distribution from sawing and milling of thermally modified wood. Hrčková [25] studied effect of thermal modification on the color change of wooden samples.

As is already known, the intensity of heat conduction in wood depends on the anatomic direction in which it is measured (it is highest in a longitudinal direction). A heat transfer study in three anatomic directions of wood (radial, tangential, longitudinal) for four species of wood (beech, oak, spruce, poplar) has been done in detail by Pivarčiová [26,27]. In both cases, the subject of the study was the heat transfer through unmodified wood.

In this research, the temperature fields above heated wood samples modified by the ThermoWood method [1] were observed with the use of holographic interferometry. This technique enables the visualization of temperature fields and the real-time tracking of events at a boundary layer of a wood ambient environment without affecting the process by measuring devices. The main objective was to gain new information about the properties of this material; mainly time dependencies, the continual course of heat transfer and an overall survey of temperature.

\section{Materials and Methods}

\subsection{Sample Preparation}

Samples of spruce (picea abies L.) wood were used for the research. A tree was cut in Slovakia at an altitude of $440 \mathrm{~m}$. At the Technical University in Zvolen, lateral radial planks with a longitudinally oriented grain with dimensions of $20 \times 100 \times 700 \mathrm{~mm}$ were sawn from the log and dried to a moisture content of $8 \%$. After drying, samples were heat treated by the ThermoWood method. The heat treatment was set to final temperatures of $160,180,200$ and $220^{\circ} \mathrm{C}$ with a final moisture content of $4-7 \%$. The heat treatment of samples used in this experiment was done as described in detail in a previous study on the properties of thermally modified wood [25].

Heating resulted in a change of the density of the wooden samples. The density decreased with the increasing temperature of the heat treatment. The control sample showed the highest density of $775.8 \mathrm{~kg} \cdot \mathrm{m}^{-3}$. The thermally treated samples showed 
the lowest density at the highest temperature $\left(220^{\circ} \mathrm{C}\right)$, which was a $21.51 \%$ decrease in comparison with the untreated control sample [25].

Temperatures and time intervals of the thermal modification are listed in Table 1 and are shown in Figure 1.

Table 1. Time intervals of the thermal modification of spruce [25].

\begin{tabular}{cccccccc}
\hline $\begin{array}{c}\text { Final } \\
\text { Temperature } \\
\left({ }^{\circ} \mathbf{C}\right)\end{array}$ & $\begin{array}{c}\text { I. Phase } \\
\text { (h) }\end{array}$ & $\begin{array}{c}\text { II Phase } \\
\text { (h) }\end{array}$ & $\begin{array}{c}\text { III. Phase } \\
\text { (h) }\end{array}$ & $\begin{array}{c}\text { IV. Phase } \\
\text { (h) }\end{array}$ & $\begin{array}{c}\text { V. Phase } \\
\text { (h) }\end{array}$ & $\begin{array}{c}\text { VI. Phase } \\
\text { (h) }\end{array}$ & $\begin{array}{c}\text { Sum } \\
\text { (h) }\end{array}$ \\
\hline 160 & 1.0 & 6.9 & 3.0 & 3.0 & 1.2 & 1.8 & 16.9 \\
180 & 1.0 & 7.5 & 4.5 & 3.0 & 2.0 & 1.8 & 19.8 \\
200 & 1.0 & 6.9 & 6.4 & 3.0 & 2.8 & 1.8 & 21.9 \\
220 & 1.0 & 7.5 & 8.2 & 3.0 & 3.6 & 1.8 & 25.1 \\
\hline
\end{tabular}

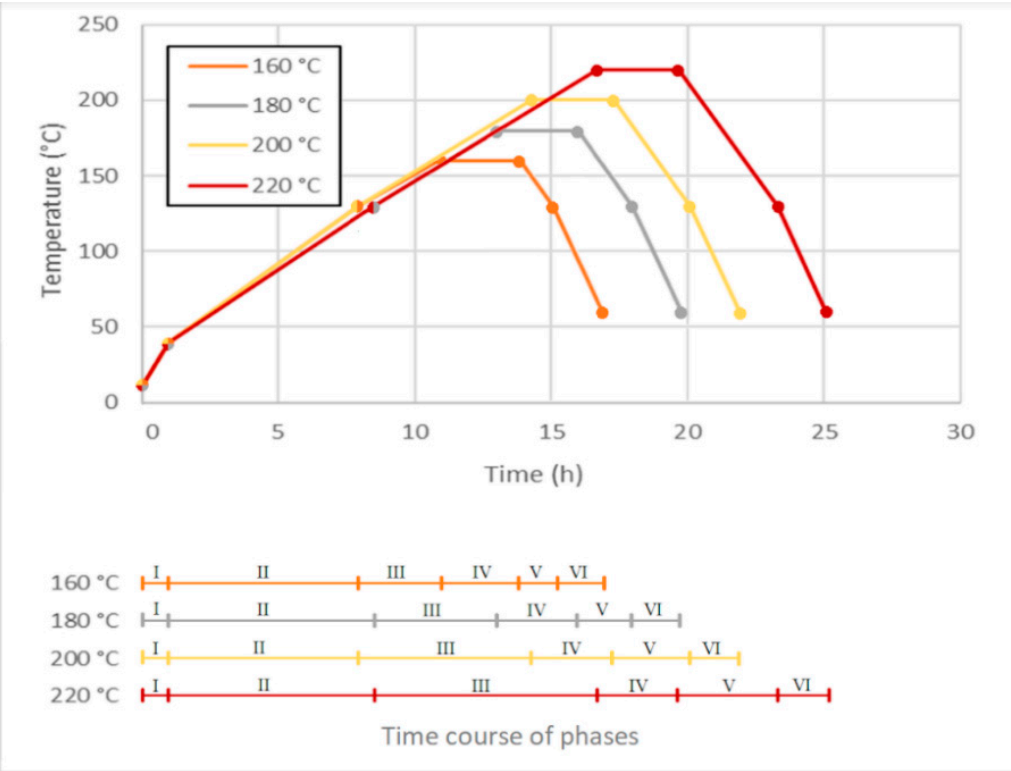

Figure 1. Course of the thermal modification of samples used in the experiment [25].

After heat treatment, $40 \times 40 \times 10 \mathrm{~mm}$ samples were cut from planks, five for each final temperature. Five control samples were cut from an untreated plank. These samples were used for the measurement of the heat transfer coefficient with the use of holographic interferometry. Samples are shown in Figure 2.

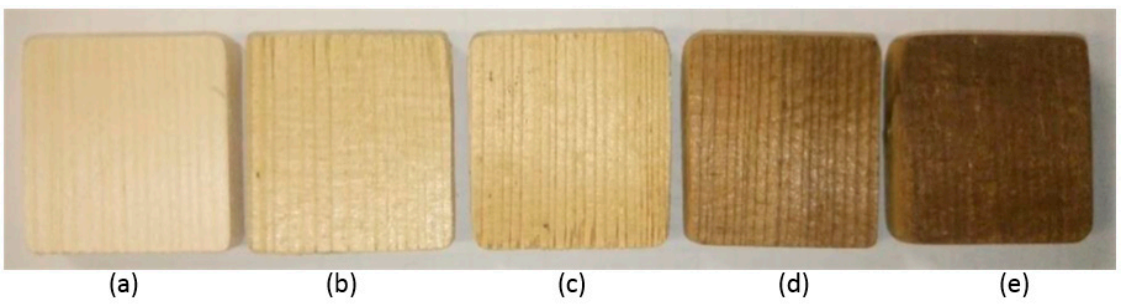

Figure 2. The control sample (a) and the thermally modified samples heated at $160{ }^{\circ} \mathrm{C}(\mathbf{b}), 180{ }^{\circ} \mathrm{C}(\mathbf{c})$, $200{ }^{\circ} \mathrm{C}(\mathbf{d}), 220^{\circ} \mathrm{C}(\mathbf{e})$.

\subsection{Holographic Interferometry Device Set-Up}

A holographic variant of the Mach-Zehnder interferometer with a configuration as shown in Figure 3 was used. This variant is one of the most used devices for the visualization and measurement of two-dimensional transparent objects. It enables a change of the focus of light beams between finite and infinite distances. 


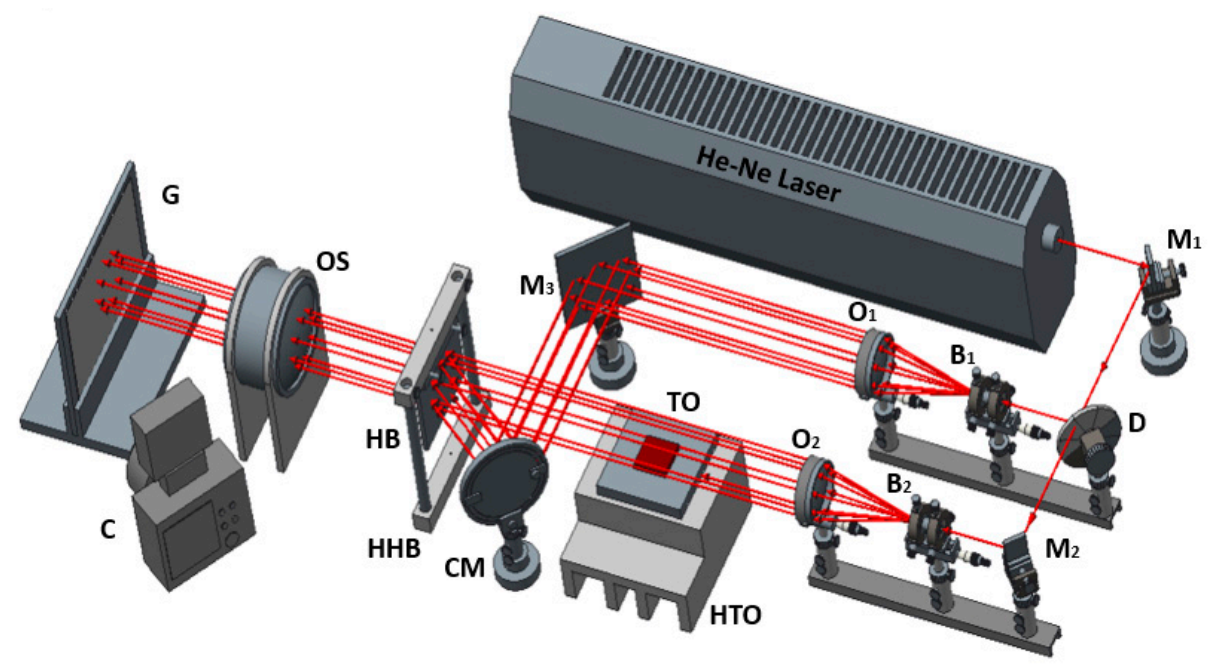

Figure 3. Configuration of a holographic variant of a single-wave Mach-Zehnder interferometer [28]. OL-object line, RL-reference line, D—divider, HB-holographic board, HHB-holder of holographic board, $\mathrm{CM}-$ mirror in cardan suspension, $\mathrm{O}_{1}, \mathrm{O}_{2}$ - object lenses, $\mathrm{M}_{1}, \mathrm{M}_{2}, \mathrm{M}_{3}$-mirrors, $\mathrm{B}_{1}$, $\mathrm{B}_{2}$ - perforated blinds, $\mathrm{MO}_{1}, \mathrm{MO}_{2}$ - microscopic object lenses, $\mathrm{TO}$-testing object, $\mathrm{HTO}$ - holder of the testing object, $\mathrm{C}$-Camera, $\mathrm{G}$ - ground glass, OS—system of object lenses.

The principle of this variant was described in detail in a previous study [28].

The Vibra program developed at the Technical University in Zvolen was used for the evaluation of obtained interferograms and for the calculation of the heat transfer coefficient.

\subsection{Analysis of Holographic Interferograms}

The analysis of holographic interferograms has been described in detail in studies of heat transfer through natural wood samples and through foam concrete [28-30].

For the evaluation of the interferograms, it is necessary to know the dependence between the state quantities of the object and the distribution of the refractive index in the optical inhomogeneity that occurs during their change.

The dependence of temperature on the state variables of the environment, on the length of the model, on the wavelength of light and on the number of dark fringes between the object and the place of the homogeneous environment can be determined according to [31] as:

$$
T(x, y)=T_{\infty} /\left[1-0.805 \cdot\left(T_{\infty}\right) /\left(l \cdot p_{\infty}\right) \cdot\left(s-\frac{1}{2}\right)\right]
$$

where $T(x, y)$ is the temperature distribution, $T_{\infty}$ is the air temperature in the reference area, $p_{\infty}$ is the pressure in the given space, $s$ is the interference order and $l$ is the length of the object.

\subsection{Calculation of the Heat Transfer Coefficient}

The heat transfer coefficient $\alpha\left[\mathrm{Wm}^{-2} \mathrm{~K}^{-1}\right]$ represents the amount of heat that transfers from the surface of the body into the fluid. Thus, it is used for the description of phenomena at the interface of a solid with a fixed arrangement of particles and the fluid in which a constant relative movement of the particles is present. In this experiment, the solid object was the wooden sample and the fluid was the ambient air. The value of the heat transfer coefficient depends on the dimensions and shape of the wall, the properties of the fluid and the hydrodynamic conditions in the fluid. In general, the heat transfer coefficient $\alpha$ can be described as a function of parameters [32]:

$$
\alpha=f \cdot\left(w, \rho, \mu, c_{p}, \lambda, \beta, g, \tau, t_{w}, l_{1}, l_{2}, \ldots\right)
$$


where $w$ is the velocity, $\rho$ is the density, $\mu$ is the dynamic viscosity, $c_{p}$ is the specific heat, $\lambda$ is the thermal conductivity, $\beta$ is the coefficient of thermal expansion, $t_{f}$ is the fluid temperature, $t_{w}$ is the wall temperature, $\tau$ is the time and $l_{1}, l_{2}$ are the characteristic geometric dimensions.

The local value of the heat transfer coefficient can be calculated with use of the equation [29]:

$$
\alpha_{x}=-\lambda_{v} \cdot(\Delta T / \Delta y)_{x} \cdot 1 /\left(T_{x}-T_{\infty}\right)
$$

where $\lambda$ is the coefficient of the thermal conductivity of the ambient air (for dry air at $20^{\circ} \mathrm{C}$, $\left.\lambda_{v}=2524 \mathrm{~W} \cdot \mathrm{m}^{-1} \mathrm{~K}^{-2}\right),(\Delta T / \Delta y)_{x}$ is the derivation of the temperature at position $x, T_{x}$ is the body surface temperature at point $x$ and $T_{\infty}$ is the temperature of the ambient air.

As the analysis of interferograms enables the determination of the temperature distribution in the fluid in detail, the method for the calculation of the heat transfer coefficient from the temperature derivatives is a useful tool in interferometric research of the heat transfer.

\subsection{Data Selection}

The method of holographic interferometry was used in the experiment. This allowed the visualization of the distribution of temperature fields over the heated sample. To be able to obtain useful data, it was necessary for the interferograms to contain at least two interference fringes. This required a sufficient temperature difference between the sample and the ambient air. This condition was met at the 12th-25th minute of sample heating.

\section{Results}

During the heating of the samples, heat transfer occurred and a thermal boundary layer formed above the samples. Interference fringes formed in this layer. At low temperatures, there were few fringes; their number increased during the experiment. This sequence is shown in Figure 4.

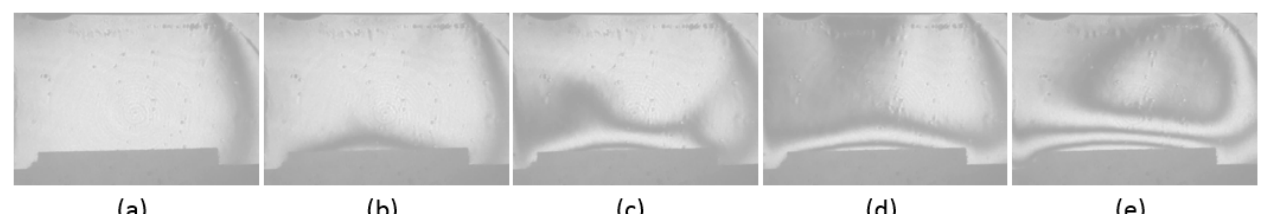

(a)

(b)

(c)

(d)

(e)

Figure 4. Sequence of formation of the interference fringes during heating. (a) Sample at the beginning of heating. (b) Formation of the first fringe, $6 \mathrm{~min}$. (c) Beginning of the formation of the second fringe, $13 \mathrm{~min}$. (d) Fully formed second fringe, $15 \mathrm{~min}$. (e) Three visible fringes, $22 \mathrm{~min}$.

The interference patterns were projected onto a screen and were recorded by a camera at $15 \mathrm{~s}$ intervals. A two sample per minute interval was chosen from the obtained images. The temperature profile of the thermal boundary layer above the sample was obtained by the analysis of interferograms using the Vibra program. The program used the implemented Equations (1) for the calculation of the temperature and (3) for the calculation of the heat transfer coefficient. Each interferogram was analyzed at five sections. The resulting coefficient for each interferogram was calculated as a mean of five acquired values.

An example of the evaluation of the temperature profile above the sample is shown in Figure 5.

The dependency of the heat transfer coefficient on the heating time was tested by a linear correlation regression of mean values. The results are summarized in Table 2 and are graphically presented as a scatter plot in Figure 6. For better clarity, calculated regression parameters are shown separately in Table 3. 


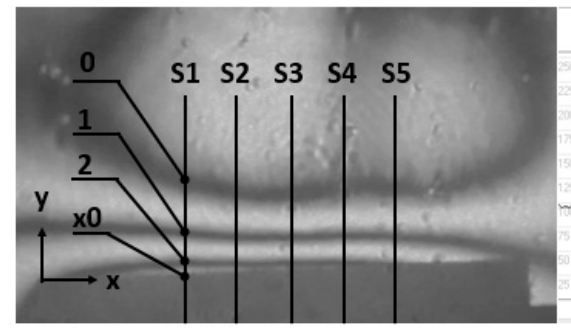

(a)

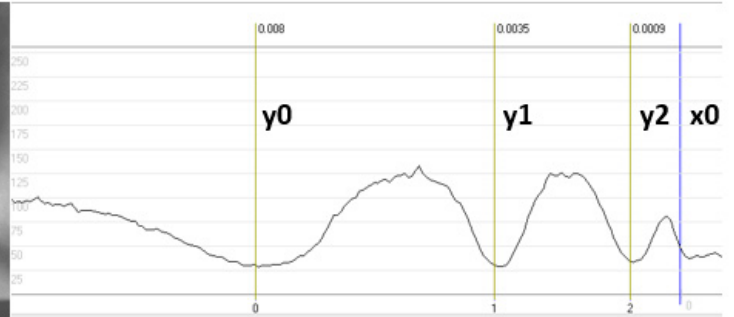

(b)

Figure 5. Evaluation of the temperature profile above the sample (spruce treated at $180{ }^{\circ} \mathrm{C}$, surface temperature $\left.55^{\circ} \mathrm{C}\right)$. (a) Evaluated interferogram where section lines $\left(\mathrm{S}_{1}-\mathrm{S}_{5}\right)$ are shown indicating the position where interferograms were evaluated. (b) Locations of the interference fringes (y0; y1; y2) and the surface of the heated sample $(\mathrm{x} 0)$ in the $\mathrm{S}_{1}$ section.

Table 2. Calculated values of the heat transfer coefficient $\alpha$. Results are means (standard deviation).

\begin{tabular}{cccccc}
\hline & \multicolumn{5}{c}{ Final Temperature of Heat Treatment $\left[{ }^{\circ} \mathbf{C}\right]$} \\
\hline Heating Time [min] & Control & $\mathbf{1 6 0}$ & $\mathbf{1 8 0}$ & $\mathbf{2 0 0}$ & $\mathbf{2 2 0}$ \\
\hline 13 & $21.58(1.32)$ & $21.26(0.92)$ & $20.09(1.54)$ & $14.84(0.79)$ & $11.14(0.67)$ \\
15 & $19.42(0.64)$ & $19.07(0.48)$ & $17.97(0.1)$ & $13.51(0.86)$ & $10.2(0.64)$ \\
17 & $17.25(1.22)$ & $16.89(0.92)$ & $15.85(0.85)$ & $12.18(0.83)$ & $9.26(0.63)$ \\
19 & $15.09(1.28)$ & $14.7(0.36)$ & $13.73(1.13)$ & $10.85(0.87)$ & $8.32(0.81)$ \\
21 & $12.93(1.02)$ & $12.52(0.54)$ & $11.61(0.89)$ & $9.53(0.55)$ & $7.38(0.65)$ \\
23 & $10.76(0.66)$ & $10.34(0.85)$ & $9.48(0.84)$ & $8.2(0.66)$ & $6.44(0.4)$ \\
25 & $8.6(0.54)$ & $8.15(0.78)$ & $7.36(0.42)$ & $6.87(0.55)$ & $5.5(0.49)$ \\
\hline mean & $15.63(0.94)$ & $15.25(0.63)$ & $14.26(0.89)$ & $11.19(0.7)$ & $8.56(0.52)$ \\
\hline
\end{tabular}

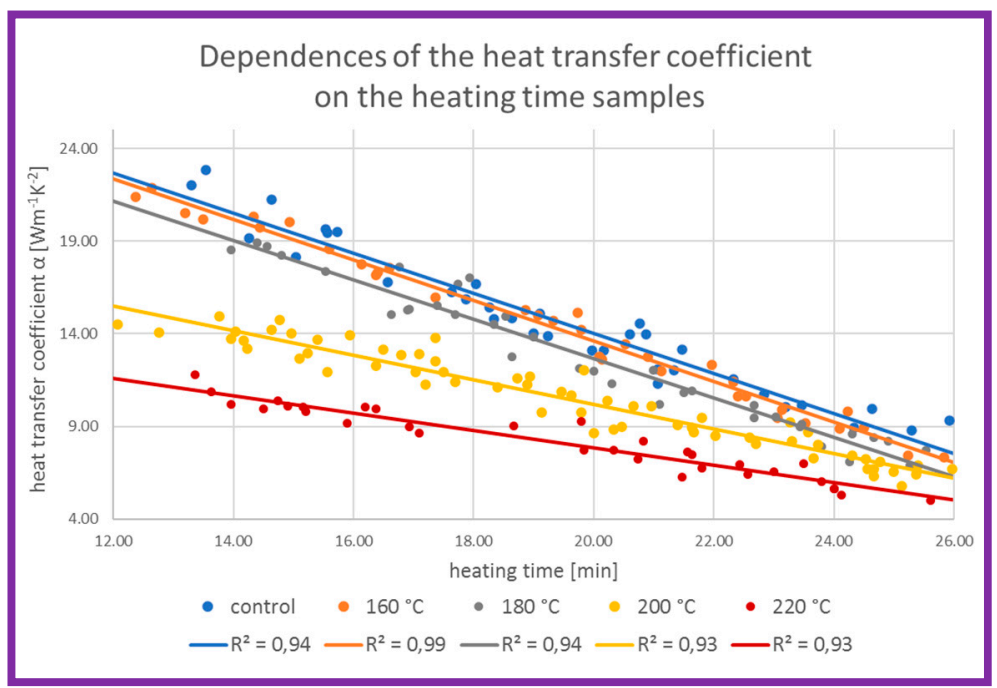

Figure 6. Dependences of the heat transfer coefficient on the heating time samples.

Table 3. Results of the linear regression test.

\begin{tabular}{cccccc}
\hline & Control & $\mathbf{1 6 0}{ }^{\circ} \mathbf{C}$ & $\mathbf{1 8 0}{ }^{\circ} \mathbf{C}$ & $\mathbf{2 0 0}{ }^{\circ} \mathbf{C}$ & $\mathbf{2 2 0}{ }^{\circ} \mathbf{C}$ \\
\hline$r$ & -0.971 & -0.993 & -0.977 & -0.964 & -0.962 \\
$t$-test & -23.374 & -47.441 & -26.624 & -28.477 & -19.377 \\
$p$-level & 0.000 & 0.000 & 0.000 & 0.000 & 0.000 \\
Equation & $y=35.641-1.082 x$ & $y=35.453-1.092 x$ & $y=33.874-1.06 x$ & $y=23.471-0.664 x$ & $y=17.25-0.47 x$ \\
\hline
\end{tabular}


To determine the influence of different heat treatment on the heat transfer coefficients of samples calculated via holographic interferometry, an analysis of variance (ANOVA) was used. This analysis was conducted for a significance level $p=5 \%$. The results are listed in Table 4. As a part of this analysis, the confidence intervals of the heat transfer coefficient of each sample were calculated. These were calculated for $95 \%$ confidence and are shown in Figure 7.

Table 4. Analysis of variance (ANOVA) between heat transfer coefficients of samples with different treatment results.

\begin{tabular}{|c|c|c|c|c|c|c|c|}
\hline \multirow{2}{*}{ Sample (Mean) } & \multirow{2}{*}{$\begin{array}{c}\text { Data } \\
\text { Normality } \\
p \text {-level }\end{array}$} & \multirow{2}{*}{$\begin{array}{c}\text { Variance } \\
\text { Analysis, } p\end{array}$} & \multicolumn{5}{|c|}{ Tuckey HSD Unequal Sample Size Significance Test } \\
\hline & & & Control & $160^{\circ} \mathrm{C}$ & $180^{\circ} \mathrm{C}$ & $200{ }^{\circ} \mathrm{C}$ & $220{ }^{\circ} \mathrm{C}$ \\
\hline Control (15.63) & 0.260 & & & 0.996 & 0.104 & 0.000 & 0.000 \\
\hline $160^{\circ} \mathrm{C}(15.25)$ & 0.128 & & 0.996 & & 0.229 & 0.000 & 0.000 \\
\hline $180^{\circ} \mathrm{C}(14.21)$ & 0.040 & 0.000 & 0.104 & 0.229 & & 0.045 & 0.000 \\
\hline $200^{\circ} \mathrm{C}(11.19)$ & 0.010 & & 0.000 & 0.000 & 0.045 & & 0.040 \\
\hline $220^{\circ} \mathrm{C}(0.52)$ & 0.237 & & 0.000 & 0.000 & 0.000 & 0.040 & \\
\hline
\end{tabular}

$95 \%$ confidence intervals of mean heat transfer coefficients $\alpha$ at tested treatment levels

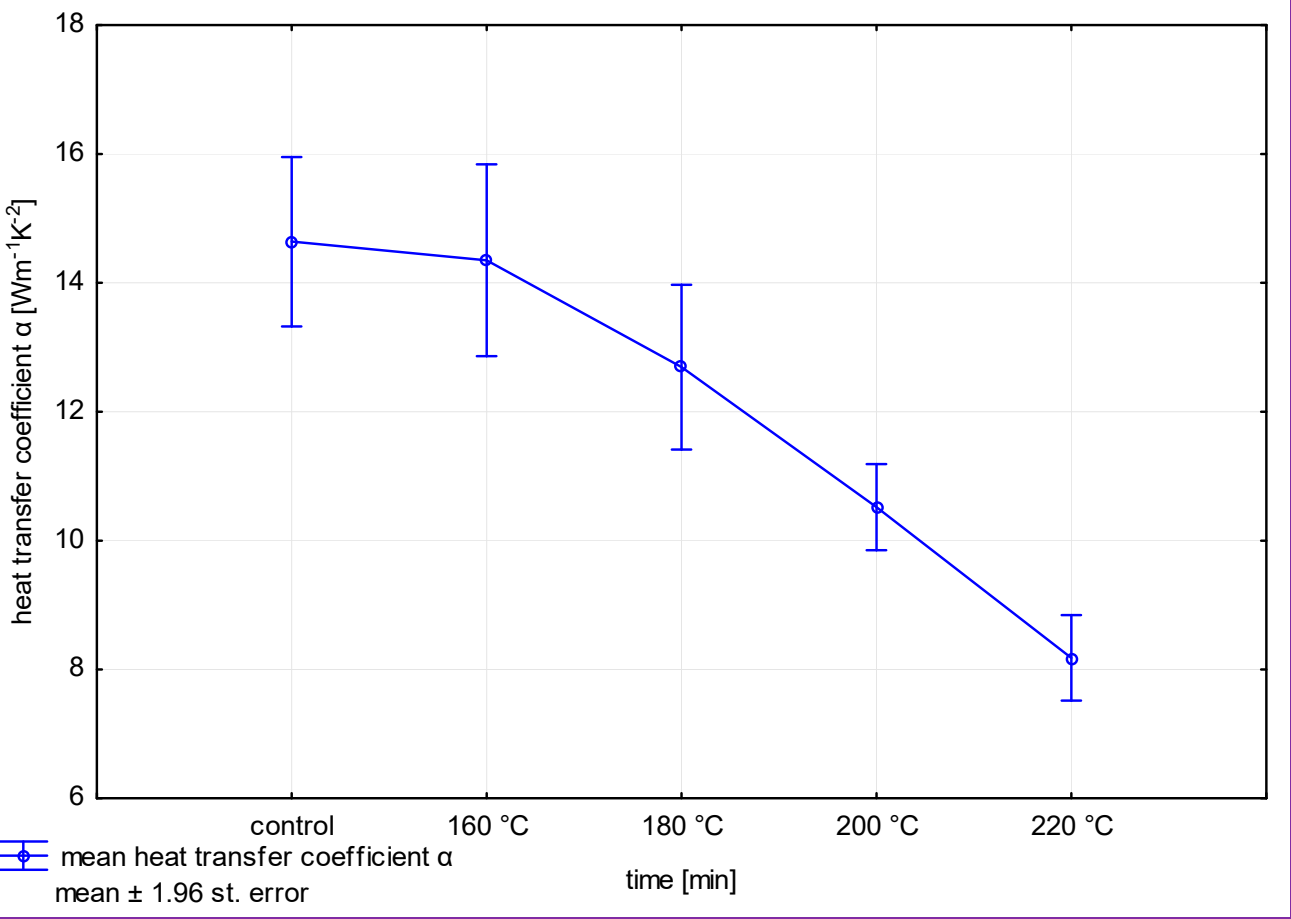

Figure 7. Box plot of $95 \%$ confidence intervals of the mean heat transfer coefficient $\alpha$ at tested treatment levels.

\section{Discussion}

The change of heat transfer coefficients during the time of the experiment was evaluated first for each sample individually. These changes followed a model of linear regression and the evaluation is summarized in Tables 2 and 3 and Figure 6.

The differences between the control sample and the sample modified at $160{ }^{\circ} \mathrm{C}$, as can be deducted from Table 2, were in the range of $-5 \%$. The differences between the samples treated at $160{ }^{\circ} \mathrm{C}$ and $180{ }^{\circ} \mathrm{C}$ were in range of $5-9 \%$. Between the samples modified at $180{ }^{\circ} \mathrm{C}$ and $200{ }^{\circ} \mathrm{C}$, the difference ranged between $6-25 \%$ for $200{ }^{\circ} \mathrm{C}$ and $16-17 \%$ for $220{ }^{\circ} \mathrm{C}$. According to the results in Table 2, the difference range was smaller at the end of the experiment $\left(\alpha=8.6-5.5 \mathrm{Wm}^{-2} \mathrm{~K}^{-1}\right)$ than at the beginning $\left(\alpha=22.66-11.61 \mathrm{Wm}^{-2} \mathrm{~K}^{-1}\right)$. 
In Figure 6, it is shown that the value of the heat transfer coefficient $\alpha$ for all samples of the thermally modified wood was lower than the value corresponding to the control sample. In the observed range, the change of the heat transfer coefficient during heating could be described by a significant linear regression. As is visible in Figure 6, the $\alpha$ coefficients decreased with heating time. The same could be conducted from the correlation coefficients shown in Table 3. All samples showed $r<-0.94$. The proximity of this coefficient to the value -1 indicated that the correlation was significant and the fact that this coefficient was negative meant that the correlation was negative; $\alpha$ decreased with time. From the $t$-test of the regression coefficient with the $p$-level shown in Table 3, a large significance could be stated for the use of the linear model.

The coefficients of determination $R^{2}$ from Figure 6 showed that an appropriate model was used. For the sample treated at $160{ }^{\circ} \mathrm{C}, R^{2}=0.99$ meant that $99 \%$ of values were described by the model with the remaining $1 \%$ considered as random influences. For the control and the $180^{\circ} \mathrm{C}$ samples, the determination coefficient totaled $R^{2}=0.94$. For $200{ }^{\circ} \mathrm{C}$ and $220^{\circ} \mathrm{C}$, the result was $R^{2}=0.93$.

In the second part of the data evaluation, a variation analysis (ANOVA) was used to prove the significance of the thermal modification effect on the heat transfer coefficient of wooden samples. The results of this analysis are summarized in Table 4 and Figure 7.

As shown in Table 4, the control sample and the $160^{\circ} \mathrm{C}, 180^{\circ} \mathrm{C}$ and $220^{\circ} \mathrm{C}$ samples passed the test of data distribution normality. According to the Tuckey test results in Table 4, the most significant differences occurred between the untreated control sample and the $200{ }^{\circ} \mathrm{C}$ and $220^{\circ} \mathrm{C}$ samples with confidence nearing $100 \%$. Between the $200{ }^{\circ} \mathrm{C}$ and $220^{\circ} \mathrm{C}$ samples, the confidence was $96 \%$. Between the $180^{\circ} \mathrm{C}$ and $200^{\circ} \mathrm{C}$ samples, a still significant confidence was observed, reaching $95.5 \%$. An influence with a smaller confidence could be claimed for the difference between the untreated sample and the sample treated at $160{ }^{\circ} \mathrm{C}$ $(90 \%)$ and for difference between the $160{ }^{\circ} \mathrm{C}$ and $180{ }^{\circ} \mathrm{C}$ samples $(78 \%)$.

This result is visually represented in Figure 7 where distributions of means of heat transfer coefficients are shown as box diagrams of $95 \%$ confidence.

Contrary to the hot and cold plate method used by $[12,15,16]$, holographic interferometry was used for the data evaluation. The obtained results led to similar conclusions; thermal modification influenced the heat transfer coefficient. The degree of wood treatment also had an effect. The heat transfer coefficients of samples treated at lower temperatures were generally higher than the heat transfer coefficients of samples modified at higher temperatures.

\section{Conclusions}

The experiment showed that the thermal modification of wood reduced the intensity of the heat transfer. In comparison with the control sample (natural untreated wood), the thermally modified samples achieved lower final values of heat transfer coefficients in the whole range of measurements. Samples modified at $200{ }^{\circ} \mathrm{C}$ and $220^{\circ} \mathrm{C}$ showed significant differences compared with both the control samples and the samples modified at $160{ }^{\circ} \mathrm{C}$ and $180^{\circ} \mathrm{C}$. The heat transfer coefficient $\alpha$ decreased with an increase in the degree of thermal modification.

The experiment showed that thermal modification has a positive effect on wood when used as a barrier to heat loss. According to the mean values in Table 2, the heat transfer coefficient was on average reduced by $3 \%$ for the $160^{\circ} \mathrm{C}$ sample, at $180{ }^{\circ} \mathrm{C}$ by $9 \%$, at $200{ }^{\circ} \mathrm{C}$ by $28 \%$ and at $220^{\circ} \mathrm{C}$ by $44 \%$ when compared with the untreated control sample.

According to Equation (2), when used in outdoor conditions, the heat transfer will be additionally affected by atmospheric conditions such as humidity, air pressure and the presence and intensity of air flow. The heat transfer coefficient depends on the temperature differences at the interface so the change of the seasons and the alternation between days and nights will also influence its value.

The heat transfer coefficient $\alpha$ also decreased with the gradual heating of the samples. A decrease of the heat transfer coefficient during sample heating followed a model of 
linear regression. At the beginning of the measurement, the control unmodified sample had a heat transfer coefficient $\alpha=22.66 \mathrm{Wm}^{-2} \mathrm{~K}^{-1}$, which, by the end of the experiment, decreased to $\alpha=8.6 \mathrm{Wm}^{-2} \mathrm{~K}^{-1}$. The decrease was from $\alpha=21.26$ to $8.15 \mathrm{Wm}^{-2} \mathrm{~K}^{-1}$ for the $160{ }^{\circ} \mathrm{C}$ sample, 20.09 to 7.36 for the $180{ }^{\circ} \mathrm{C}$ sample, 14.84 to 6.87 for the $200{ }^{\circ} \mathrm{C}$ sample and 11.14 to 5.5 for the $220^{\circ} \mathrm{C}$ sample. When compared with the untreated sample, the heat transfer coefficients of the modified samples at $160,180,200$ and $220^{\circ} \mathrm{C}$ respectively, decreased to $99 \%, 93 \%, 68 \%$ and $51 \%$ of the maximal control value $\alpha=22.66 \mathrm{Wm}^{-2} \mathrm{~K}^{-1}$ at the beginning of the experiment and to $95 \%, 86 \%, 80 \%$ and $64 \%$ of the minimal value of the control sample $\alpha=8.6 \mathrm{Wm}^{-2} \mathrm{~K}^{-1}$ by the end of the experiment. This decrease could be due to the higher air temperature in the boundary layer. In the presence of heated air, the temperature difference in the proximity above the sample surface was lower than the temperature difference between the sample surface and the ambient air.

When compared with studies on the thermal conductivity of thermally modified natural fir and beech wood [12] and spruce and poplar wood [15], similar results were obtained. This study, focusing on the heat transfer coefficient, led to the results being dispersed in a larger range than the results of studies on the thermal conductivity of thermally modified wood [12,15]. The differences could occur due to multiple factors such as the type of wood, moisture content or variations in the time intervals of the heat treatment. In further experimentation, more samples should be used for testing. An experiment could also be done where holographic interferometry and the hot and cold plate method would be used for the examination of samples of same origin and treatment.

The holographic interferometry method shows a potential to be an effective tool in the study of heat transfer by the visualization of temperature fields. It could be applied to a variety of materials such as aerated concrete [28] or to test the functionality of heat exchange surfaces [33]. Holographic interferograms with the use of the Fourier-Mellin transformation could find applications in automation processes by enabling the calculations of shift and the rotation of images [34,35].

The novelty of this work is in the application of holographic interferometry for the visualization of thermal fields and for the measurement of the heat transfer through thermally modified wood. This method presents a sufficient tool and useful addition to the field of wood science. Comparative studies of holographic interferometry with methods that are already in use are in preparation, aiming to prove the reliability of this new method.

Author Contributions: Conceptualization, methodology, experiments, investigation, validation, visualization, supervision, project administration, funding acquisition, E.P. Resources, writingoriginal draft preparation, writing-review and editing, data curation, Á.H. Experiments, formal analysis, P.K. All authors have read and agreed to the published version of the manuscript.

Funding: The article is funded by the VEGA project 1/0086/18.

Institutional Review Board Statement: Not applicable.

Informed Consent Statement: Not applicable.

Acknowledgments: This research was funded by VEGA 1/0086/18: Researching Temperature Fields in a Set of Shaped Heat Transfer Surfaces.

Conflicts of Interest: The authors declare no conflict of interest.

\section{References}

1. Kain, G.; Idam, F.; Federspiel, F.; Réh, R.; Krišt'ák, L'. Suitability of Wooden Shingles for Ventilated Roofs: An Evaluation of Ventilation Efficiency. Appl. Sci. 2020, 10, 6499. [CrossRef]

2. International Thermowood Association. Thermo Wood Handbook; Unioninkatu: Helsinky, Finland, 2003; 66p, Available online: https:/ / asiakas.kotisivukone.com/files/en.thermowood.palvelee.fi/downloads/tw_handbook_080813.pdf (accessed on 2 October 2020).

3. Stamm, A.J.; Hansen, L.A. Minimizing Wood Shrinkage and Swelling Effect of Heating in Various Gases. Ind. Eng. Chem. 1937, 29, 831-833. [CrossRef] 
4. Seborg, R.; Millett, M.A.; Stamm, A.J. Heat-Stabilized Compressed Wood (Staypack): Technical Report; Department of Agriculture, Forest Service, Forest Products Laboratory: Madison, WI, USA, 1956; 11p, Available online: https: / www.fpl.fs.fed.us/documnts / fplr/fplr1580.pdf (accessed on 15 October 2020).

5. Kollmann, F.; Schneider, A. Über das Sorptionsverhalten wärmebehandelter Hölzer. Holz Als Roh- Und Werkst. 1963, 21, 77-85. [CrossRef]

6. Burmester, A. Einfluß einer Wärme-Druck-Behandlung halbtrockenen Holzes auf seine Formbeständigkeit. Holz Als Roh- Und Werkst. 1973, 31, 237-243. [CrossRef]

7. Giebeler, E. Dimensionsstabilisierung von Holz durch eine Feuchte/Wärme Druck-Behandlung. Holz Als Roh- Und Werkst. 1983, 41, 87-94. [CrossRef]

8. Reinprecht, L.; Vidholdová, Z. Mould resistance, water resistance and mechanical properties of OHT-thermowoods. In Sustainability through New Technologies for Enhanced Wood Durability, Proceedings of the Socio-Economic Perspectives of Treated Wood for the Common European Market Final Conference, Bordeaux, France, 29-30 September 2008; Ghent University: Gent, Belgium, 2008; pp. 159-165, ISBN 9789080656505.

9. Boonstra, M. A Two-Stage Thermal Modification of Wood. Doctor's Thesis, Université Henri Poincaré, Nancy, France, 2008. Available online: https:/ / hal.univ-lorraine.fr/tel-01748345/document (accessed on 10 December 2020).

10. Niemz, P.; Hoffman, T.; Rétfalvi, T. Investigation of chemical changes in the structure of thermally modified wood. Maderas. Cienc. Tecnol. 2010, 12, 67-78. [CrossRef]

11. Kol, S.H.; Keshin, S.A. The thermal conductivity of solid wood heat-treated using the thermowood method. In Proceedings of the Interational Conference on Material Science and Technology in Cappadoccia (IMSTEC'16), Nevsehir, Turkey, 6-8 April 2016; Kurt, B., Carboga, C., Öztürk, B.Z., Eds.; pp. 942-946. Available online: https:/ / www.imstec.org/yazim_formatlari/IMSTEC $\backslash T 1$ $\backslash$ textquoteright16\%20PROCEEDINGS\%202.revize.pdf (accessed on 7 January 2021).

12. Kol, H.S..; Sefil, Y. The thermal conductivity of fir and beech wood heat treated at 170, 180, 190, 200, and $212{ }^{\circ}$ C. Appl. Polym. Sci. 2011, 121, 2473-2480. [CrossRef]

13. Korkut, D.; Hiziroglu, S.; Aytin, A. Effect of Heat Treatment on Surface Characteristics of Wild Cherry Wood. BioResources 2013, 8, 1582-1590. [CrossRef]

14. Olarescu, C.M.; Campean, M.; Cosereanu, C. Thermal conductivity of solid wood panels made from heat-treated spruce and lime wood strips. PRO Ligno 2015, 11, 377-382.

15. Pásztory, Z.; Horváth, N.; Börcsök, Z. Effect of heat treatment duration on the thermal conductivity of spruce and poplar wood. Eur. J. Wood Wood Prod. 2017, 75, 843-845. [CrossRef]

16. Czajkowski, Ł.; Olek, W.; Weres, J. Effects of heat treatment on thermal properties of European beech wood. Eur. J. Wood Wood Prod. 2020, 78, 425-431. [CrossRef]

17. Barcík, Š.; Gašparík, M. Effect of Tool and Milling Parameters on the Size Distribution of Splinters of Planed Native and Thermally Modified Beech Wood. BioResources 2014, 9, 1346-1360. Available online: https:/ / ojs.cnr.ncsu.edu/index.php/BioRes/article/ view / 4990 (accessed on 1 October 2020). [CrossRef]

18. Kol, H.S..; Sefil, I.; Aysal, S. Effect of heat treatment on the mechanical properties, and dimensional stability of fir wood. In Proceedings of the 27th International Conference Research for Furniture Industry, Ankara, Turkey, 17-18 September 2015; pp. 269-279. Available online: http:/ / www.furnituredesign2015.org/assets/icrfi_tr_138.pdf (accessed on 7 January 2021).

19. Kubs, J.; Gašparík, M.; Gaff, M.; Kaplan, L.; Čekovská, H.; Ježek, J.; Štícha, V. Influence of Thermal Treatment on Power Consumption during Plain Milling of Lodgepole Pine (Pinus contorta subsp. murrayana) BioResources 2017, 12, 407-418.

20. Koleda, P.; Korčok, M.; Barcík, Š.; Il'aš, Š. Effect of temperature of heat treatment on energetic intensity of flat milling of picea abies. Manag. Syst. Prod. Eng. 2018, 26, 151-156. [CrossRef]

21. Korčok, M.; Koleda, P.; Barcík, Š.; Vančo, M. Effect of technical and technological parameters on the surface quality when milling thermally modified European oak wood. Manag. Syst. Prod. Eng. 2018, 26, 151-156. [CrossRef]

22. Cui, X.; Matsumura, J. Wood Surface Changes of Heat-Treated Cunninghamia Inaceolate Following Natural Weathering. Forests 2019, 10, 791. [CrossRef]

23. Kačíková, D.; Kubovský, I.; Ulbriková, N.; Kačík, F. The Impact of Thermal Treatment on Structural Changes of Teak and Iroko Wood Lignins. Appl. Sci. 2020, 10, 5021. [CrossRef]

24. Kminiak, R.; Orlowski, K.A.; Dzurenda, L.; Chuchala, D.; Banski, A. Effect of Thermal Treatment of Birch Wood by Saturated Water Vapor on Granulometric Composition of Chips from Sawing and Milling Processes from the Point of View of Its Processing to Composites. Appl. Sci. 2020, 10, 7545. [CrossRef]

25. Hrčková, M.; Koleda, P.; Koleda, P.; Barcík, Š.; Štefková, J. Color Change of Selected Wood Spieces Affected by Thermal Treatment and Sanding. BioResources 2018, 13, 8956-8975. Available online: https:/ / bioresources.cnr.ncsu.edu/resources/color-change-ofselected-wood-species-affected-by-thermal-treatment-and-sanding/ (accessed on 10 December 2020). [CrossRef]

26. Pivarčiová, E. Possibilities of Visualization and Analysis of Temperature Fields at Thermic Degradation of Wood. Dissertation Thesis, Technická univerzita vo Zvolene, Zvolen, Slovak, 2002.

27. Pivarčiová, E.; Barcík, Š.; Štefková, J.; Škultéty, E. Investigation of Temperature Fields in the Air Environment above Wood Subjected to Thermal Degradation. Drv. Ind. 2019, 70,319-327. Available online: https://hrcak.srce.hr/index.php?show=clanak\& id_clanak_jezik=334009 (accessed on 16 February 2021). [CrossRef] 
28. Pivarčiová, E.; Božek, P.; Domnina, K.; Škultéty, E.; Fedosov, S. Interferometric measurement of heat transfer above new generation foam concrete. Meas. Sci. Rev. 2019, 19, 153-160. [CrossRef]

29. Vizualizační a Optické Měricí Metody. Available online: https:/ / eu.fme.vutbr.cz/file/vomm/index.htm (accessed on 10 January 2021).

30. Possibilities and Prospects of Holography. Available online: http://www.holografia.wz.cz/holography/index.php (accessed on 12 October 2020).

31. Černecký, J.; Koniar, J.; Brodnianska, Z. Optimalizácia Výmenníkov Tepla s Využitím Experimentálnych Metód a Fyzikálneho Modelovania; Technická univerzita vo Zvolene: Zvolen, Slovak, 2012; ISBN 978-80-228-2325-8.

32. Kossaczký, E.; Surový, J. Chemické Inžinierstvo I, 3rd ed.; Slovenské vydavatel'stvo technickej a ekonomickel literatúry: Bratislava, Slovak, 1963; pp. 250-252.

33. Brodnianska, Z. Experimental investigation of convective heat transfer between corrugated heated surfaces of rectangular channel. Heat Mass Transf. 2019, 55, 3151-3164. [CrossRef]

34. Božek, P. Automated Detection Type Body and Shape Deformation for Robotic Welding Line. In Advances in Systems Science, Advances in Intelligent Systems and Computing; Swiątek, J., Grzech, A., Swiątek, P., Tomczak, J., Eds.; Springer: Cham, Switzerland, 2014; Volume 240, pp. 229-240.

35. Božek, P.; Pivarčiová, E. Registration of Holographic Images Based on Integral Transformation. Comput. Inform. 2012, 31, 1369-1383. Available online: http:/ / www.cai.sk/ojs/index.php/cai/article/view/772/0 (accessed on 7 January 2021). 